University for Business and Technology in Kosovo

UBT Knowledge Center

Oct 28th, 9:00 AM - Oct 30th, 5:00 PM

\title{
Albanian's audio-visual information in Kosovo from the year 1945-1990
}

Ferid Selimi

University for Business and Technology, ferid.selimi@ubt-uni.net

Follow this and additional works at: https://knowledgecenter.ubt-uni.net/conference

Part of the Social and Behavioral Sciences Commons

\section{Recommended Citation}

Selimi, Ferid, "Albanian's audio-visual information in Kosovo from the year 1945-1990" (2016). UBT International Conference. 33.

https://knowledgecenter.ubt-uni.net/conference/2016/all-events/33

This Event is brought to you for free and open access by the Publication and Journals at UBT Knowledge Center. It has been accepted for inclusion in UBT International Conference by an authorized administrator of UBT Knowledge Center. For more information, please contact knowledge.center@ubt-uni.net. 


\title{
Albanian's audio-visual information in Kosovo from the year 1945-1990
}

\author{
Ferid Selimi \\ UBT - Higher Education Institution, Lagjja Kalabria, 10000 p.n., \\ Prishtine, Kosovo \\ ferid.selimi@ubt-uni.net
}

\begin{abstract}
Albanian information via radio waves emanate in Kosovo in 1945. Respectively, Radio Pristina, was the first audio media in Kosovo that saw light, and originally had headquarters in Prizren. Thirty years later, precisely in 1975, the capital of Kosovo (then an autonomous province within the former Yugoslavia) opens an information window in albanian, also with visual images. So, it was 1975 when the television started launching a program, which informed the albanian kosovars in albanian language. These two mediums for albanians living in the former Yugoslavia were the most heard mediums, respectively viewed.

Nevertheless, this information lasted 45 years through radio, namely 15 years on television, until the serbian government headed by Milosevic took the decision to close these two media, also having dismissed all albanian employees and accepting subsequently unskilled employees, and among them, also albanians who stood loyal to Milosevic's government and continued to do the work of journalists and moderators in TVP, which medium, albanians of the former Yugoslavia, from 1990 until 1999, neither heard nor watched.
\end{abstract}

Keywords: albanian, information, Kosovo, Radio, Televizion

\section{Introduction}

After the Second World War Kosovo was a province, its name was The Socialist Autonomous Province of Kosovo; it was a constituent element of Yugoslavia but within the framework of Republic of Serbia. Since then, Kosovo used to have its borders, territory and the people who lived in it. Although there were these three elements of making a state, factors that make a state, but still Kosovo remained within Serbia $^{1}$, but at the same time it used to be a constituent element ${ }^{2}$, which by the Constitution of Yugoslavia guaranteed all the state rights, had all governing bodies such as Presidency of the Socialist Autonomous Province of Kosovo, President of the Presidency, the Parliament, the Executive Council, Provincial Committee, Chamber of Commerce etc. and in all aspects it had the autonomy in management and the right in taking a decision. Based on this fact, together with six republics and the Autonomous Province of Vojvodina, Kosovo also had its right in informing its people in their mother

\footnotetext{
${ }^{1}$ Ustav SFRJ 1974 clan 1
}

${ }^{2}$ Po aty, clan 2 
Book of Proceedings

International Conference on Social Sciences, Humanities, and other sciences

tongue. Specifically, there was the Article 12 of the law for information in Yugoslavia which regulated the right to information through media. Here is what the law said, "The nations and nationalities of the Socialist Autonomous Province of Kosovo have the right to be informed through the media in their own language and alphabet" 3 , therefore, using the civic right to information in the language of nations and nationalities that lived in the territory of Yugoslavia, Kosovo also needed to form its media ${ }^{4}$, written and audio-visual in the language of the nations and nationalities that lived there.

The first steps of visual information in Kosovo

While at some European countries, especially in Britain, France and Czech Republic, the first radios had started to transmit programs on the twenties of the last century, but never forgetting the fact that even in Serbia especially in Belgrade at the end of twenties it was established Radio Belgrade. In Kosovo a radio transmitter was founded after the Second World War and that was Radio Prishtina. This media started the program in Albanian language but at the very beginning its center was in Prizren. The daily program of Radio Prishtina was not a long one. It started with two hours daily program. It is good to stress out, this radio had started two hours program even in 1945. So when we compare the data, Radio Prishtina is ranked as the last one established radio in ex-Yugoslavia.

\subsection{The first steps of visual information in Kosovo}

Unlike Radio Prishtina, Television of Prishtina started to work thirty years later in 1974, with an unsatisfactory equipment and old electronic technology.5 In this summer of this year came the auto reportage (OB Van) the first one with four cameras B/Z. With these equipment started broadcasting, from the studios of Prishtina Television in Prishtina. However, due to the inexperience of technical operators and the lack of technique, still Television of Prishtina had no capacity to finalize the realized programs. The whole material for program was shooting with film technique and later on it was sent to Belgrade where it was edited and later the same program be transmitted. This way of finalization of the filmed emission lasted up to 29 November 1975.6 Since that day, Television of Prishtina managed to broadcast its programs now from Prishtina without the help of Belgrade. Although in the beginning, in these two mediums there were employed a small number of people, and there was a very weak network distributors, anyway the Albanians had the opportunity to follow the programs in Albanian language, both radio and television spoke in Albanian language in Kosovo. Later on, with the independence of media and with the development of technology and well educated working staff, the program and the staff were enlarged. In addition to it, the distributed network grew out and RTP could be seen not only in Kosovo but also in some villages in Serbia, Macedonia and Montenegro which were near to the border of Kosovo. "From this media institution there were broadcasted 11 hours of television programs and 43 hours radiophonic programs in three channels".7 Although it is not understandable for that time, considering the capacity (having always in mind the time when it was established and acted) of making informative productions in RTP.

\footnotetext{
${ }^{3}$ Sluzbeni list SAPK, br. 7. Zakon o Javnom informisanju, str 188, 8 mart 1974

${ }^{4}$ Balle, Francis: Mediat \& Shoqëritë. Faqe 11.

${ }^{5}$ https://sq.wikipedia.org/wiki/Radio_Televizioni_i_Prishtin\%C3\%ABs

${ }^{6}$ Ferid Selimi. Transmetuesi publik fq. 17

${ }^{7}$ Hamit Boriçi, e Mark Marku. Histori e shtypit shqiptar. faqe 247
} 


\section{The challenges of Radio Television of Prishtina}

Every informative house, even more famous than RTP in that socialist state was faced with different problems especially with transmissions live from the field. Comparing to other informative houses, RTP which was newly formed informative house with an inexperienced staff and with a small number of people, obviously ranked itself somewhere in the end of the list considering its capabilities. All this was because of the recent war, where the poverty was so deep. Even the wealth that the people had inherited or gained, it was taken a great part of it on the name of the people, party and homeland.

The possibility of extending the information and information via radio and television was very small. It was the time, when the quality of information products, especially information once the emergency had passed, and had been taken the first steps towards an evolution of the first schools, for example journalism and technique. ${ }^{8}$ The early sixties of the XX century, it was a time when it had started the recovery of economy and with it, also the houses of information, which were in a very small number. In Kosovo the number of information houses was smaller than at the other parts of Yugoslavia. Nothing could pass without being filtered in the organs of the Communist Party. In Kosovo there was still only Radio Prishtina as audio medium, which informed the Albanian citizens. Anyway, the economical developments changed the circumstances even in other fields of life, together with it there was a need for the new development in other spheres of life. In this way even the media changed its format and obviously there was a quite improvement. In this trend, even in the former Yugoslavia, although the Medias were formed within the structures of state information through one party system, the services and information were not left behind ${ }^{9}$ providing leisure services, which were directed at meeting the demand of users, respectively state, respectively to population. Since Kosovo was not a state, RTP ${ }^{10}$ did not have the convenience of serving information products independently as their partners did, in Britain for example, to avoid political pressure and economic dependence. Legislation was enacted in a way that it did not depend on the state policy. But in the former Yugoslavia, although the law and the Constitution foresaw free information as an inalienable right of the citizen, however the media was controlled by the government. Therefore, there was not only RTP that was controlled, but all the media in the former Yugoslavia, more or less. However, without forgetting the political vicissitudes, all the media went through different stages of development. Therefore, the RTP as informative medium passed through these stages, even phases of the nineties were the darkest, when RTP, not that there was no chance to develop in any way, but had no luck either to act freely.

\section{The Serbian authorities invaded the media.}

The Serbian Government suprimmed everything that was considered a social and a state property, this happened in 1989. In 1990 closed the RTP, a state medium. In this way after the supreme of "Rilindja" and the expelling of the workers from their jobs, Kosovo and Albanians were left without any information in Albanian language. Following the events in Kosovo, and seeing that life was not functioning properly, and seeing that slowly all windows of information were closed, Albanian Radio Television helped to Radio Television of Prishtina, offering a time from its edition at 20:00 o'clock time, to the program evening news. Meanwhile Radio Pristina was lucky to have an edition within ten

\footnotetext{
${ }^{8}$ Ferid Selimi. Transmetuesi publik. Fq. 19-20

${ }^{9}$ Balle, Francis: Mediat \& Shoqëritë. Faqe 79

${ }^{10}$ Bruno Ollivier. Shkencat e Komunikimit. Fq. 87
} 
Book of Proceedings

International Conference on Social Sciences, Humanities, and other sciences

minutes of news edition of Radio Zagreb, at 18 and 30 minutes, five days a week, from Monday to Friday. So this was the opportunity of informing the Albanian people during the nineties in Kosovo. On the other hand, the interest of Albanians to be informed into Albanian language by RTP became overshadowed.

\section{Final Reviews}

We have to mention once again that the first media appeared in 1945 and it was broadcasted by Radio Prishtina with its center in Prizren. The information in Albanian language through radios in Kosovo takes place in 1945. Thirty years later there were better circumstances in Prishtina, the capital of Kosovo (that time so called The automnous Province within the framework of ex-Yugoslavia was opened a window of information in Albanian language in visual form. In this way, in 1975 started the emission of the television program informing the Albanians in their mother tongue. Both these mediums had a common house. So both of them were within the framework of Radio Television of Prishtina but their function was done into two buildings. The building where used to work Television of Prishtina was the place near the Green Market, nowadays it is RTK, where as Radio Prishtina was near the Rectorate of the University of Prishtina where today is functioning Radio Kosovo and Kohavision. This medium, which was suppressed with violence by Serbian authorities in 1990, by the time it broadcasted program in the languages in Kosovo, which, daily program was filled more with the program in Albanian, was among mediums mostly watched in the entire territory of the former Yugoslavia where Albanians live. And this information, which lasted for 45 years, or 15 years, it was just a unique voice of all Albanians in the former Yugoslavia. Giving that voice and picture to every Albanian houses in the former Yugoslavia, but this was considered as an obstacle to the accomplishment of various projects of the Serbian regime directed against Kosovo Albanians who lived in Kosovo. The Serbian government with its leader Milosevic, decided to shut down the media, dismissed all Albanian workers and accepted later on unskilled workers, and among them a small number of Albanians loyal to the Serbian authorities, who continued to work as journalists and moderators in TVP-in, but Albanians in exYugoslavia never listened or followed these programs, they never believed information this media was offering to them.

\section{References}

1. Balle, Francis. Mediat\&Shoqëritë. Papirus. Tiranë, 2011

2. Barbier, Frederik e Chaterina. B. Lavenir. Historia e medias- nga Dideroi tek interneti. ISHM. Tiranë, 2004

3. Bianku, Ledi. Të Drejtat e Njeriut në Evropë. Botim i Qendrës Evropiane. Tiranë, 2001

4. Boriçi, Hamit e M. Marku. Histori e shtypit shqiptar. SHBLU. Tiranë, 2010

5. Claude-Jean, Bertrand. Deontologjia e medieve. ISHM. Tiranë, 2007

6. Dervishi, Zyhdi. Lente të ndërveprimit simbolik. Emal. Tiranë, 2008

7. Dominick, R. Joseph. Dinamika e komunikimit masiv. UETPRESS, Tiranë, 2010

8. Duhamel, Oliver. E Drejta Kushtetuese. Logos - A: Shkup, 2004 
9. Dhima, Dh. Aleksandër. Hyrje në Antropologji. Botim i tretë. Ideart, Tiranë, 2010-Eko, Umberto. Si bëhet një punim diplome. Botime përpjekja, Tiranë, 1997

10. Fuga, Artan. Rrota e mundimit. Dudaj. Tiranë, 2007

11. Fuga, Artan. Brirët e dhisë. Ora. Tiranë, 2008

12. Fuga, Artan. Media, politika, shoqëria 1999-2000. Dudaj. Tiranë, 2008-Dej, A. Luis. Etika u medijama. Klub plus. Beograd, 2008

13. Djorgjeviç, Toma. Teorija informacija. SITJ. Beograd, 1989

14. Djorgjeviç, Toma. Komunikacija i vlast. VEI. Beograd, 1988

15. Ismaili, Hilmi \& Fatmir Sejdiu. Historia e Shtetit dhe e së Drejtës. Prishtinë, 2002

16. Ismaili, Osman: Fillet e së Drejtës, Prishtinë, 2004

17. Ismaili, Osman: Filozofia e së Drejtës. Prishtinë, 20067.

18. Kasimati, Mimoza \& Mimoza Manxhari. Sjellje Organizative. SHBLU. Tiranë, 2005

19. Kuhn, Tomas. Struktura e Revolucioneve Shkencore. CEU PRES. Dukagjini. Pejë, 1997

20. K. Spiker. Komunikimi organizativ. Përktheu: Belina Budina. UET/ PRESS. Tiranë, 2009

21. Mcnair, Brian. Hyrje në komunikimin politik. UETPRESS (Botim i katërt). Tiranë, 2009

22. Ollivier, Bruno. Shkencat e Komunikimit. Papirus. Tiranë. 2015.

23. Papa, J. Michael e Tom D. Daniels \& Barry K. Spiker. Komunikimi organizativ. Përktheu: Belina Budina. UET/ PRESS. Tiranë, 2009

24. Popper, Karl. Mjerimi i historicizmit. Onufri. Tiranë, Pa vit botimi.

25. Rachels, James. S. Rachels. Elementet e filozofisë morale ISP\&Dita. Tiranë, 2000

26. Selimi, Ferid. Transmetuesi publik. Jehona. Prishtinë, 2016

27. Tomiç, Zorica. Komunikologija. Çigoja. Beograd, 2003

28. Weber, Max. Politika si profesion. Asdreni. Shkup, 2006

29. Veljanovski, Rade. Javni RTV servil u sluzbi gradjana. Clio. Beograd, 2005

30. Vitiç, A. Volter e Çarls F. Shuler. Audio-vizuelna sredstva-njihova priroda i upotreba. Vuk Karadziç. Beograd, 1966

31. Council Of Europe: Konventa për mbrojtjen e pakicave kombëtare, Strasburg, Prepared in electronic format by the Council of Europe Field Office in Tirana. March, 2003

32. Evropska Konvencija Za Zastitu Ljudskih Prava i Osnovnih Sloboda. Rim, 4 novembra 1950, 4 novembra 2000

33. Evropska povelja o regionalnim i manjinskim jezicima. Strazbur, 5 Novembra 1992

34. Këshilli i Evropës: Hyrje në Marrëveshjen Kuadër për Mbrojtjen e Pakicave Kombëtare. tetor 1998 H (98) 5 rev 3, 1999

35. Medijski javni servis gradjana. www.rts.rs/sr/javniservis https://en.wikipedia.org/wiki/Radio Television of Serbia

36. http://en.wikipedia.org/wiki/Radio Televizioni Shqiptar

37. http://www.lexisnexis.com/en-us/about-us/about-us.page http://www.propublica.org/about

38. http://www.journalism.org/node/231

39. http://www.gazetastart.com/

40. http://www.dw.de/gazetaria-investigative-n\%C3\%AB-shqip\%C3\%ABri/a-15523028-1

41. http://lajme.shqiperia.com/lajme/artikull/iden/386707/titulli/Gazetaria-investigative 
Book of Proceedings

International Conference on Social Sciences, Humanities, and other sciences

42. http://www.coe.int/t/dghl/monitoring/minorities/6resources

43. http://www.indeksonline.net/?FaqeID $=2 \&$ LajmID $=46340$

44. https://sq.wikipedia.org/wiki/Radio_Televizioni_i_Prishtin\%C3\%ABs

45. http://sfrj-jugoslavija.forumotion.com/t2-ustav-1974 